\title{
反回神経麻痺症例の臨床統計的観察
}

\author{
木崎 久喜・黒川 浩伸*·中村光士郎*
}

\section{Clinical Analysis of 109 Patients with Recurrent Laryngeal Nerve Paralysis}

\author{
Hisanobu Kisaki \\ (Shin-Nittetsu Hirohata Hospital) \\ Hironobu Kurokawa and Koshiro Nakamura \\ (Ehime Prefectural Central Hospital)
}

One hundred and nine patients with recurrent laryngeal nerve paralysis (RLNP), who consulted our hospital over the past five years (1991 1995), were investigated clinically.

The following results corroborated those of other RLNP studies.

1) Males were more frequently affected than females.

2) In unilateral RLNP, the left vocal cord was affected two times more frequently than the right side and the vocal cord was mainly fixed at the paramedian position.

Other results differed somewhat from those of previous studies:

1) No difference was seen in the mean age between males and females, because many cases in both males and females were caused by malignant tumors.

2) Hoarseness or dyspnea was the most frequent complaint in the patients with unilateral and bilateral paralysis, respectively. Stridor in a child case with unilateral paralysis was interesting as another complaint. This observation indicates that careful examination of this complaint is essential in children.

3) Paralysis unrelated to surgery (unoperative paralysis) was observed in 76 patients (69.7\%) while post-operative paralysis was observed in 33 patients (30.3\%). Causes in 33 of the 76 patients with unoperative paralysis were malignant tumors, and lung cancer was the most common malignancy in both males and females. Esophageal cancer was the second most frequent malignancy in males and metastatic lesions from breast cancer was second most frequent in females. Therefore, not only lung cancer but also breast cancer warrants close attention in females. The incidence of RLNP with malignant tumors was highest in the age group which was in their seventies. Careful inspection along the RLN is important, especially among older patients.

Key words : recurrent laryngeal nerve paralysis (RLNP), malignant tumor, hoarseness, dyspnea, stridor 


\section{はじめに}

反回神経はその走行が長いため, 様々な原因によって 麻痺を生じらることは周知のことであり, 反回神経麻痺 と診断した場合にはその原因究明が極めて重要となる. また，原因には麻㽻を取り扱った施設の特徵が反映され ることが多い. 今回, 愛媛県立中央病院耳鼻咽喉科飞拉 いて取り扱った反回神経麻瘏症例の臨床統計的検討を行 ったので若干の文献的考察を加光て報告する.

\section{対象と方法}

1991年 1 月より 1995年 8 月までの 4 年 8 力月間に当科 に颃いて, 反回神経麻痺と診断した 109 例の年齢, 性別, 声帯麻痺側, 麻痺声帯位, 主訴, 受診の経緯および原因 そついて調査した。

\section{結果}

（1）年齢招よび性別頻度

図 1 亿示したように性別では男性 62 例 (56.9\%)，女性 47例 (43.1\%) と男性に多くみられた。年齢別頻度では男 性は60歳代に, 女性は70歳代に最も多く2られ, 全体と しては60歳代にピークを有する単峰性の分布を示した。 平均年齢は男性が58.3歳, 女性が61. 1歳で男女差は注と んどみられなかった。

(2) 麻痺側および麻痺声帯位

一側麻痺は92例 (84.4\%), 両側麻痺は17例(15.6\%)で あった。また, 一側麻痺では右側が 31 例 $(28.4 \%)$, 左側

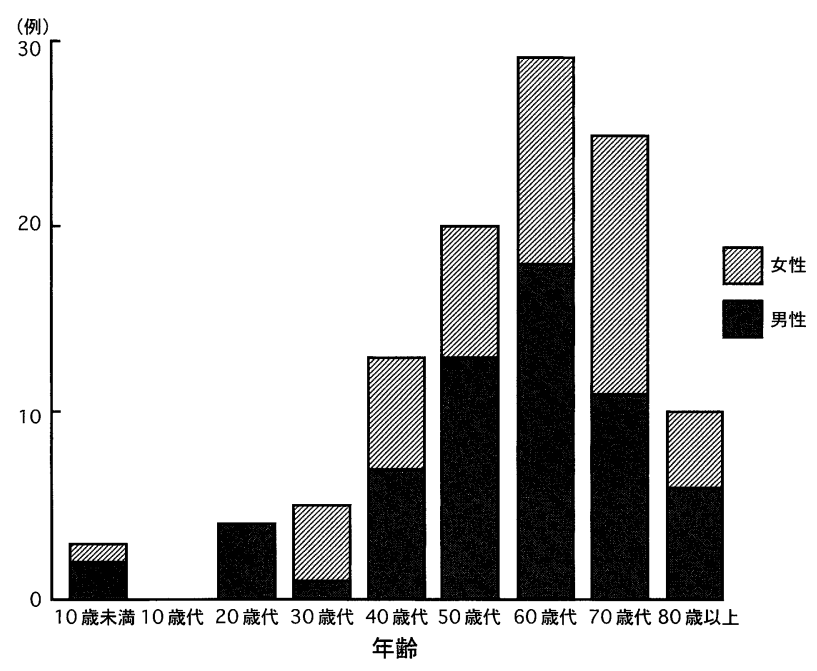

図 1 年齢・性別頻度
が61例(56.0\%)で，左側が右側の約 2 倍の頻度であった. 麻痺声帯位の内訳について表 1 亿示す。一側麻痺では副 正中位が92例中 61 例 $(66.3 \%)$ で最も多く, 両側麻痺では 両側正中位が17例中 8 例 (47.1\%) で最も多く2られた。

(3) 主 訴

一側麻痺と両側麻痺に分けて主訴を表 2 飞示す。一側 麻痺では嗄声が92例中 80 例 $(87.0 \%)$ と最も多かったのに 対して, 両側麻痺では呼吸困難が17例中10例 (58.8\%)で 最も多くみられた。また一側麻盘では嗄声の他に曣下障 害, 呼吸困難, 喘鳴を主訴とする症例もみられた。その 他の中には咽喉頭異常感や，咳嗽などが含まれている.

一側麻痺に扣いて喘鳴を主訴とした症例は 1 歳の幼児で あった，両側麻痺では喘鳴, 嗄声を主訴とする症例はみ られたが，䀻下障害を主訴とする症例はみられなかった。

\section{(4) 受診の経緯}

109例の受診の経緯と原因検索の状況について表 3 に 示す. 他科, あるいは他院からの紹介患者は91例, 非紹 介患者は18例で，当院が地域医療の基幹病院であるとい う性質を反映し，紹介患者が高い割合を占めていた。ま た，当科において原因検索を行った症例と，行わなかっ た症例に分けて分類すると, 検索を行った症例が28例,

表 1 麻痺声帯位

\begin{tabular}{|c|c|c|c|}
\hline - & 側 麻 瘒 & 両 側 & 麻 痺 \\
\hline 副正中位 & 61 例 ( $66.3 \%)$ & 両側副正中位 & 3例 $(17.5 \%)$ \\
\hline 正中位 & $11(12.0)$ & 両側正中位 & $8 \quad(47.1)$ \\
\hline 中間位 & $7 \quad(7.6)$ & 両側中間位 & $2(11.8)$ \\
\hline 開大位 & $2(2.1)$ & 両側開大位 & $0 \quad(0.0)$ \\
\hline \multirow[t]{2}{*}{ 不全麻痺 } & $11 \quad(12.0)$ & 両側不全麻痺 & $2(11.8)$ \\
\hline & & 一側副正中位 $\cdot$ & $2(11.8)$ \\
\hline 合 & 92例 (100.0\%) & 計 & 17例(100.0\%) \\
\hline
\end{tabular}

表 2 主 訴

\begin{tabular}{c|c|c}
\hline \hline & 一側麻痺 & 両側麻痺 \\
\hline 嗄 声 & 80 例 $(87.0 \%)$ & 4 例 $(23.5 \%)$ \\
呼吸困難 & $2 \quad(2.2)$ & $10 \quad(58.8)$ \\
嚥下障害 & $4(4.3)$ & $0 \quad(0.0)$ \\
喘 鳴 & $1 \quad(1.1)$ & $3 \quad(17.7)$ \\
その他 & $5(5.4)$ & $0 \quad(0.0)$ \\
\hline 合 計 & 92 例 $(100.0 \%)$ & 17 例 $(100.0 \%)$
\end{tabular}


表 3 受診の経緯・原因検索の状況

\begin{tabular}{c|c|c|c}
\hline \hline & 紹介患者 & 非紹介患者 & 合 \\
\hline 当科にて原因検索 & & & \\
Lた症例 \\
病巣あり \\
病巣不明
\end{tabular}

行わなかった症例が81例であった．前者のらち13例では 原因が判明し，15例では判明しなかった。後者に拈いて 原因推定可能症例とは，受診時に紹介状あるいは現病歴 より麻痺の原因疾患を推定しらる情報が得られたため， 特に当科に执いて原因検索を施行しなかった症例であり， 67例(61.5\%)を占めていた。また，原因不明症例とは， 受診時に原因を推定しらる情報がなかったにもかかわら ず検索を行わなかった症例であり，患者自身が検査を希 望しなかった症例や，他の重篤な合併症のため十分な検
査を行えなかった症例である。

（5）原 因

原因別の頻度を表 4 に示す. 109例のらち術後性麻痺 は33例 (30.3\%)，非術後性麻痺は76例(69.7\%)であった。 術後性麻痺では挿管性が11例(10.1\%)で最も多く, 次 いで甲状腺手術後が 9 例 (8.3\%)，心臓・大血管手術後 が 6 例 (5.5\%)であった. 尚，反回神経の走行と無関係 な部位の手術後に麻痺を生じた症例は挿管性麻痺として 取り扱った。また，非術後性麻痺では肺癌が19例(17.4

表 4 麻痺原因と麻痺側

\begin{tabular}{|c|c|c|c|c|c|c|}
\hline & 手術部位 & 左側 & 右側 & 両側 & 合 & 計 \\
\hline \multirow[t]{7}{*}{ 術後性 } & 挿管性 & 4例 & 2例 & 5例 & \multicolumn{2}{|c|}{ 11例(10.1\%) } \\
\hline & 甲状腺 & 2 & 5 & 2 & \multicolumn{2}{|c|}{$9 \quad(8.3)$} \\
\hline & 心·大血管 & 5 & 1 & 0 & \multicolumn{2}{|c|}{$6 \quad(5.5)$} \\
\hline & 食道 & 2 & 1 & 1 & \multicolumn{2}{|c|}{$4 \quad(3.7)$} \\
\hline & 頸部 & 2 & 0 & 0 & \multicolumn{2}{|c|}{$2 \quad(1.8)$} \\
\hline & 肺 & 1 & 0 & 0 & \multicolumn{2}{|c|}{$1 \quad(0.9)$} \\
\hline & 合 計 & 16例 & 9例 & 8例 & \multicolumn{2}{|c|}{33 例 (30.3\%) } \\
\hline
\end{tabular}

\begin{tabular}{|c|c|c|c|c|c|}
\hline & 疾 患 & 左側 & 右側 & 両側 & 計 \\
\hline \multirow[t]{9}{*}{ 非術後性 } & 肺癌 & 16例 & 2例 & 1例 & 19例 (17.4\%) \\
\hline & 特発性 & 8 & 6 & 1 & $15 \quad(13.8)$ \\
\hline & 食道癌 & 1 & 3 & 0 & $4 \quad(3.7)$ \\
\hline & 縦隔リンパ節転移 & 3 & 1 & 0 & $4 \quad(3.7)$ \\
\hline & 心·大血管 & 4 & 0 & 0 & $4 \quad(3.7)$ \\
\hline & 甲状腺癌 & 0 & 2 & 0 & $2(1.8)$ \\
\hline & その他 & 7 & 6 & 1 & $14 \quad(12.8)$ \\
\hline & 原因不明 & 6 & 2 & 6 & $14 \quad(12.8)$ \\
\hline & 合 計 & 45例 & 22例 & 9例 & 76例 $(69.7 \%)$ \\
\hline
\end{tabular}


\%)で最も多く，次いで特発性が15例(13.8\%)みられた。 原因別に声帯麻痺側をみると, 術後性麻㽻では, 抻管 性は両側麻疩が 11 例中 5 例と多く, 甲状腺手術後は 9 例 中 5 例が右側麻痺，また心臓・大血管手術後は 6 例中 5 例が左側麻痺であった。非術後性麻痺では, 肺癌は19例 中16例と左側麻㽻が多く, 心蔵・大血管は全例が左側麻 㽻であった。

（6）悪性腫瘍による麻痺

非術後性麻痺のらち悪性腫瘍により生じた麻痺の原因 疾患を性別に表 5 亿示す. 悪性腫瘍による麻痺は 33 例で 全体の $30.3 \%$ 占め, 男性では19例, 女性では14例にみ られた，男女とも肺癌が最も多く，男性では19例中10例， 女性では14例中 9 例を占めていた. 男性では肺癌以外に 食道癌が 4 例で多く, 次渭癌括よび食道癌を原発巣と する縱隔リンパ節転移が 2 例みられた。 その他に甲状腺 癌, 頸部悪性リンパ腫, 縱隔腫瘍がそれぞれ 1 例ずつみ られた．女性では肺癌以外に縦隔リンパ節転移が 2 例, 頸静脈孔症候群と頸部リンパ節転移がとれぞれ 1 例及ら れ，いずれも乳癌が原発巣であった。また，甲状腺癌も 1 例又られた。

\section{考察}

反回神経麻痺の臨床統計的検討は本邦でもこれまで多 数報告されて抢り，これらの報告と今回の結果を比較検 討した.

従来の報告を総合して比較すると, 性別では男性にや や多くみられたこと, 一側麻痺に沶いては左側麻痺が右 側麻痺の約 2 倍の頻度であったこと, また一側麻痺では

表 5 悪性腫瘍による麻痺の性別頻度

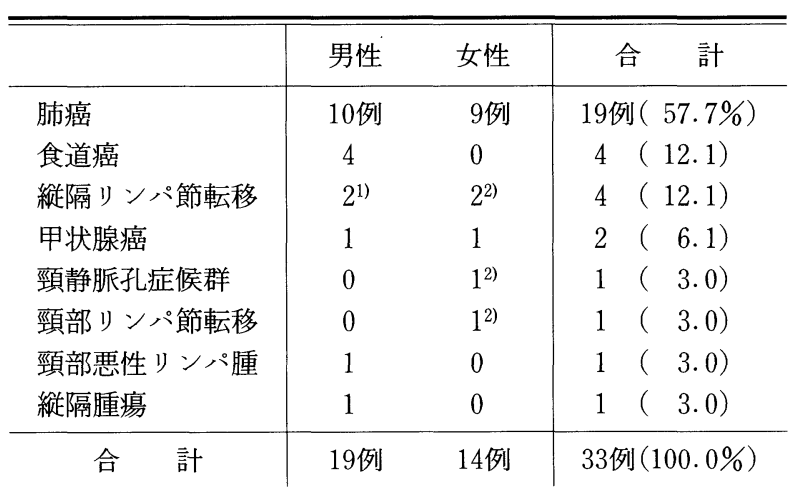

1 ）原発巣は胃癌 1 例之食道癌 1 例

2) 原発巣は乳癌
副正中位固定が圧倒的に多かったことなどは今回の結果 と同様であった．以下に従来の報告と若干異なる点につ いて考察した.

(1) 年齢分布

男性は60歳代を中心に高龄者に多く，女性はそれより も若い世代に多くみられるとの報告が多(1) 4)，今回の 検討では男女とも50歳代から70歳代に集中して招り，平 均年齢に差はみられなかった。これは任ら）の報告と同 椂に男女とも悪性腫瘍による麻痺が多かったこと，末た， 中年女性に好発する甲状腺疾患による麻痺が少なかった ことなどが関係していると考觉られた。

(2) 主 訴

主訴については，1歳の幼児例で喘鳴を主訴に受診し た一側麻痺の症例が含まれていた．乳幼児の場合，一側 麻痺であっても嗄声よりも，喘鳴などの上気道の狭窄症 状から反回神経麻痺が発見されることがあるので注意が 必要である。

（3）術後性麻痺

術後性麻痺では挿管性, 甲状腺手術後, 心臓・大血管 手術後の順に多くみられた。これは甲状腺手術後が最も

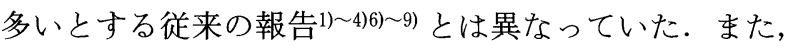
插管性麻痺は腹部外科手術後に多いとする報告10) 12) が あるが，当科では挿管性麻痺の11例のらち脳手術が 4 例 で最子多く，次に消化器手術が 3 例含まれていた。これ は, 術後性麻痺の原因がその施設の特殊性を反映するた めと考兄られた。

また，挿管性麻痺の麻痺側について，左側麻瘏が多い とする報告17781121313 が汪とんであるが，今回の検討では 両側麻痺が最も多くみられた。これは挿管性麻痺が生じ る際には, 反回神経の解剖学的特徵以外にも, カフの過 膨張やカフの位置，不適合なチューブの使用，挿管中や 麻酔中の頸部の過伸展や屈曲, 薬剂の影響, 全身状態, 加齢による反回神経の抵抗性減弱なぞが複雑に関与する ためと考兄れた。

（4）非術後性麻痺

肺癌が最も多く, この傾向は河村 $5^{3)}$, 鈴木ら ${ }^{8)}$, 小 川ら の)報告と同様であった．今回の検討に执いて肺癌 では左側麻痺が圧倒的に多くみられたが，長山ら はこ の理由を肺のリンパ流と反回神経の走行により説明して おり, 肺癌例が左側麻痺を生じた場合, ボタロー管リン パ節への転移を念頭に置く必要があるとしている。

また非術後性麻㽻のらち悪性腫瘍によるものは全体の 
$30.3 \%$ 占めていた。過去の報告2)68)14) 17)でも反回神 経麻瘏の約 3 割は悪性腫瘍により生じると考えられてい る.なかでも肺癌は男女ともその半数以上を占めて沶り, 同疾患が増加傾向にあることから反回神経麻痺併発例も 今後増加していくことが予想される．肺癌の他に男性で は食道癌が多くみられたのに対し，女性では縦隔りンパ 節転移の 2 例, 頸部リンパ節転移, 頸静脈孔症候群の各 1 例が乳癌を原発巣として牤り，特に女性の麻痺症例で は肺癌の他に乳癌の存在に留意する必要があると考えら れた。諸家の報告334889914)では肺癌の他, 食道癌, 甲状 腺癌の頻度が高いとされていたが，当科に拈いては，甲 状腺癌は男女にそれぞれ 1 例ずつみたのみであった，河 村ら ${ }^{3)}$ は麻痺原因に占める悪性腫瘍の割合は加齢ととも に増加すると報告しており，今回の検討でも悪性腫瘍に よる麻痺は70歳代にピークを認め, 高齢者に多い傾向を 示していた．従って高齢者の反回神経麻痺では特に悪性 腫瘍の存在を疑らことが肝要であると考えられた.

$$
\text { まとめ }
$$

今回, 当科に沶いて反回神経麻痺と診断した109例に ついて, 従来の報告と比較検討し以下の注目すべき結果 を得た。

1.60歳代をピークに50歳代から70歳代に集中してい た。

2. 主訴は一側麻痺では嗄声, 両側麻痺では呼吸困難 が多くみられた。 また, 乳幼児では喘鳴から麻痺が発見 されることもあるので注意が必要である。

3 . 麻痺原因は術後性麻痺では挿管性, 非術後性麻痺 では肺癌が多くみられた。

4. 悪性腫瘍による麻痺が約 3 割を占め, 高齢者に多 い傾向を示した。男性では肺癌, 食道癌による麻痺が多 く, 女性では肺癌の他に, 乳癌を原発巣とする転移病巣 による麻痺も多くみられた。

\section{参考文献}

1 ) 岩田義弘, 岩田重信, 高頔昭彦, 他 : 反回神経麻㽻の臨床
統計的観察. 耳鼻臨床 $87: 511 \sim 517,1994$.

2 ）上出洋介, 森山寛, 佐野典子, 他: 当教室に括忷る反回 神経麻痺症例の検討一最近の 5 年間一. 日気食会報 36 : 442 449, 1985.

3 ）河村裕二, 丘村 熙, 湯本英二, 他 : 反回神経麻㽻の臨床 統計的観察. 日耳鼻 $90: 1004 \sim 1009,1987$.

4 ）山田倫久, 佐藤意生, 平野 実, 他：反回神経麻痺の臨床 統計的観察. 耳喉 $53: 443 \sim 449,1981$.

5 ) 任 書喜, 久 育男, 豊田健司, 他：反回神経麻疩症例の 統計的検討. 耳鼻臨床 $84: 217 \sim 223,1991$.

6 ）佐々木良二, 吉田淳一, 松永 亨: 声帯麻疩356例の臨床 統計的観察. 耳鼻臨床 $77: 1467 \sim 1475,1984$.

7 ）長山郁生, 嘉筄秀章, 滝元 徹, 他 : 過去17年間にみられ た反回神経麻痺の臨床統計. 耳展 $29: 559 \sim 567,1986$.

8 ）鈴木八郎, 長谷川智彦, 稲村博雄, 他 : 反回神経麻痺症例 の臨床的観察. 耳鼻臨床 補51：95 101, 1991.

9 ）小川佳伸, 田中 治, 宮原 裕 : 反回神経麻痺の臨床統計 耳鼻臨床 補37 : 209 215, 1990.

10）黒川浩伸, 河村裕二, 湯本英二, 他 : 插管性反回神経麻㽻 症例の統計的観察. 耳鼻 $36: 175 \sim 177,1990$.

11）小川佳伸, 松永 喬, 宮原 裕, 他: 日生病院に括ける反 回神経麻痺の臨床統計一特に挿管性麻疩について一. 耳 鼻臨床 $87: 505 \sim 510,1994$.

12）久 育男, 豊田健司, 園田隆郎, 他 : 挿管性反回神経麻痺 症例の検討. 耳鼻 $36: 171 \sim 174,1990$.

13）田中信三, 田中康政, 藤田真知子, 他 : 反回神経麻㿁の臨 床統計と治療 -20 年間の変遷一. 耳鼻臨床 補 $62: 1 \sim 8$, 1993.

14）矢野原邦生, 久 育男, 鈴木由一, 他 : 反回神経麻㽻の臨 床像. 耳鼻臨床 $71: 1201 \sim 1207,1978$.

15) Hagan PJ : Vocal cord paralysis. Ann Otol Rhinol Laryngol $72:$ 206 222, 1963.

16) Parnell FW and Brandenburg JH : Vocal cord paralysis ; a review of 100 cases. Laryngoscope $80: 1036 \sim 1045,1970$.

17) Titche LL : Causes of recurrent laryngeal nerve paralysis. Arch Otolaryngol $102: 259 \sim 261,1976$.

$$
\left(\begin{array}{l}
\text { 原稿受付 : 平成 } 9 \text { 年 } 8 \text { 月 } 20 \text { 日 } \\
\text { 原稿採択 : 平成 } 9 \text { 年 } 11 \text { 月 } 12 \text { 日 } \\
\text { 別刷請求先 : 木崎久喜 } \\
\text { 个 } 671-1122 \text { 姫路市広畑区夢前町 } 3-1 \\
\text { 新日鉄広畑病院耳鼻咽喉科 }
\end{array}\right)
$$

